Louisiana State University

LSU Digital Commons

Faculty Publications

Department of Biological Sciences

$12-22-2006$

\title{
Epinecrophylla, a new genus of antwrens (Aves: Passeriformes: Thamnophilidae)
}

\author{
Morton L. Isler \\ Smithsonian National Museum of Natural History \\ Daniela Rodrigues Lacerda \\ Universidade Federal de Minas Gerais \\ Phyllis R. Isler \\ Smithsonian National Museum of Natural History \\ Shannon J. Hackett \\ Field Museum of Natural History \\ Kenneth V. Rosenberg \\ Cornell Lab of Ornithology
}

See next page for additional authors

Follow this and additional works at: https://digitalcommons.Isu.edu/biosci_pubs

\section{Recommended Citation}

Isler, M., Lacerda, D., Isler, P., Hackett, S., Rosenberg, K., \& Brumfield, R. (2006). Epinecrophylla, a new genus of antwrens (Aves: Passeriformes: Thamnophilidae). Proceedings of the Biological Society of Washington, 119 (4), 522-527. https://doi.org/10.2988/0006-324X(2006)119[522:EANGOA]2.0.C0;2

This Article is brought to you for free and open access by the Department of Biological Sciences at LSU Digital Commons. It has been accepted for inclusion in Faculty Publications by an authorized administrator of LSU Digital Commons. For more information, please contact ir@lsu.edu. 
Authors

Morton L. Isler, Daniela Rodrigues Lacerda, Phyllis R. Isler, Shannon J. Hackett, Kenneth V. Rosenberg, and Robb T. Brumfield 


\section{BioOne COMPLETE}

\section{Epinecrophylla, a new genus of antwrens (Aves: Passeriformes: Thamnophilidae)}

Authors: Isler, Morton L., Rodrigues Lacerda, Daniela, Isler, Phyllis R., Hackett, Shannon J., Rosenberg, Kenneth V., et al.

Source: Proceedings of the Biological Society of Washington, 119(4) : 522-527

Published By: Biological Society of Washington

URL: https://doi.org/10.2988/0006324X(2006)119[522:EANGOA]2.0.CO;2

BioOne Complete (complete.BioOne.org) is a full-text database of 200 subscribed and open-access titles in the biological, ecological, and environmental sciences published by nonprofit societies, associations, museums, institutions, and presses.

Your use of this PDF, the BioOne Complete website, and all posted and associated content indicates your acceptance of BioOne's Terms of Use, available at www.bioone.org/terms-of-use.

Usage of BioOne Complete content is strictly limited to personal, educational, and non - commercial use. Commercial inquiries or rights and permissions requests should be directed to the individual publisher as copyright holder.

BioOne sees sustainable scholarly publishing as an inherently collaborative enterprise connecting authors, nonprofit publishers, academic institutions, research libraries, and research funders in the common goal of maximizing access to critical research. 


\section{Epinecrophylla, a new genus of antwrens (Aves: Passeriformes: Thamnophilidae)}

Morton L. Isler*, Daniela Rodrigues Lacerda, Phyllis R. Isler, Shannon J. Hackett, Kenneth V. Rosenberg, and Robb T. Brumfield

(MLI, PRI) Department of Vertebrate Zoology, Birds, National Museum of Natural History, Smithsonian Institution, P.O. Box 37012, Washington, D.C. 20013-7012, U.S.A., e-mail: islermor@si.edu;

(DRL) Departamento de Biologia Geral, Instituto de Ciencias Biologicas, Universidade Federal de Minas Gerais, Av. Antônio Carlos, 6627 C.P. 486, 31.270-010 Belo Horizonte, Minas Gerais, Brasil, e-mail: danielalac@yahoo.com.br;

(SJH) Zoology Department, Field Museum of Natural History, 1400 S. Lake Shore Drive, Chicago, Illinois 60605, U.S.A., e-mail: shackett@fieldmuseum.org;

(KVR) Cornell Laboratory of Ornithology, 159 Sapsucker Woods Road, Ithaca, New York 14850-6780, U.S.A., e-mail: kvr2@cornell.edu;

(RTB) Museum of Natural Science, 119 Foster Hall, Louisiana State University, Baton Rouge, Louisiana 70803, U.S.A., e-mail: brumfld@1su.edu

Abstract.-We offer a new generic name for the stipple-throated assemblage of antwrens (Thamnophilidae) currently placed in the genus Myrmotherula. Molecular studies demonstrated that Myrmotherula is polyphyletic, with the stippled-throated group forming a clade that is not sister to any other currently recognized Myrmotherula species. The stipplethroated assemblage is distinguished morphologically by at least one sex having a black throat stippled white or buffy white combined with a comparatively long, unmarked tail, although three populations considered subspecies have lost one of these characters. The distinct evolution of this assemblage is supported by diagnostic behavioral characters derived from foraging behaviors, vocal repertoires, and nest architecture.

In a pioneering isozyme-derived phylogeny of antwrens (Thamnophilidae: Myrmotherula), Hackett \& Rosenberg (1990) identified a grouping whose species shared an obvious plumage feature, the presence of numerous pale spots on a black throat of one sex or, rarely, both sexes. They termed this clade the "checker-throated" Myrmotherula group. Earlier, Gradwohl \& Greenberg (1984) and Remsen \& Parker (1984) identified three members of the group as "dead-leaf specialists" that foraged almost entirely by searching for insects in curled dead

\footnotetext{
* Corresponding author.
}

leaves suspended above the ground. More recently, the group, now termed the "stipple-throated" assemblage, was found to possess a distinct type of vocalization used in ritualized confrontations (Zimmer \& Isler 2003). A recent molecular phylogeny of the Thamnophilidae (Irestedt et al. 2004) that included two species from the stipple-throated assemblage found that those species were probably not closely related to the genus Myrmotherula.

A name for the stipple-throated assemblage does not exist (Cory \& Hellmayr 1924). Here, we erect a genus that recognizes the monophyly and distinct nature of this assemblage. 
Epinecrophylla M. L. Isler \& Brumfield, new genus

Type species.-Formicivora haematonota Sclater, 1857.

Diagnosis, morphology.-Small birds of the family Thamnophilidae, typically (a few individual measurements fell outside these ranges) 9-11 cm long (flattened skin); mass 8-11 g; tail length 33-45 (mostly 38-44) $\mathrm{mm}$; wing chord 47$54 \mathrm{~mm}$; tarsus $15-17 \mathrm{~mm}$; bill length (from nares) $8-10 \mathrm{~mm}$; bill width (at nares) $3.5-4.3 \mathrm{~mm}$; bill depth (at nares) $3.5-4.3 \mathrm{~mm}$. All species, except E. ornata, are primarily brown (anterior underparts gray in most males, posterior upperparts red in some populations), lacking distinguishing markings on the crown or above the eye but with male having chin and part or all of throat black covered with small white spots ("stippling"). Both sexes have dark brown to black wing coverts whose apexes are typically marked with conspicuous white or buffy spots. Tail unmarked; irides typically pale (white, buffy, pale red); tarsi gray. The stipplethroated assemblage is distinguished from all other small antwrens, except $M y r-$ motherula gularis (see Discussion), by having a stippled black throat combined with unstreaked brown plumage, contrasting dark wing coverts spotted pale, tail long and unmarked, and bill long.

Molecular analysis.-Two molecular studies (Hackett \& Rosenberg 1990, Irestedt et al. 2004) that included species of both Myrmotherula and Epinecrophylla showed that they comprise at least two distinct clades that are not each others closest relative. In their isozyme study, Hackett \& Rosenberg (1990) included five Epinecrophylla species (including representatives from four populations of $E$. haematonota), 13 Myrmotherula species, and eight additional thamnophilid species from eight other genera. Although the phenogram reconstructed from the isozyme data included the anomalous placement of Pygiptila stellaris within the stippled-throated assemblage, a relationship not verified by Irestedt et al. (2004) or an ongoing study (Brumfield et al. in prep.), Hackett \& Rosenberg's (1990) phenogram illustrated both that the Epinecrophylla species grouped together and that the genus was not sister to Myrmotherula. Irestedt et al. (2004) included two Epinecrophylla species and six Myrmotherula species (the Myrmotherula tally includes Formicivora and Myrmochanes, which were found to be closely related to Myrmotherula). Their combined-data phylogeny provided support for the monophyly of Epinecrophylla and their myoglobin data suggested the genus is more closely related to Neoctantes, Microrhopias, and Myrmorchilus than to Myrmotherula.

As part of a larger study of thamnophilid phylogenetic relationships (Brumfield et al. in prep.), DNA sequences from mitochondrial and nuclear genes were collected from 104 thamnophilid species including six species from the stipplethroated group (E. gutturalis, E. fulviventris, E. leucophthalma, E. spodionota, E. haematonota, and E. erythrura) and 14 Myrmotherula species. Consistent with earlier studies, the analysis supported a tree in which the stipple-throated assemblage was monophyletic but not sister to the assemblage of Myrmotherula species. Especially significant was the finding that Myrmotherula gularis, a species that has sometimes been associated with the Stipple-throated group and which was omitted in the two prior molecular studies, was not a member of either the Epinecrophylla or Myrmotherula clades. Detailed methodologies on molecular data collection and analysis are available from R.T.B. and will be found in a forthcoming publication on the molecular systematics of the Thamnophilidae (Brumfield et al. in prep.).

Vocal analysis. - A distinct behavioral difference between Epinecrophylla and Myrmotherula species is the presence/ 
absence of a song type and related display. In ritualized confrontations, individuals of Epinecrophylla species face each other about $30 \mathrm{~cm}$ apart, lower the head, fluff out the back plumage, and pivot from side to side, incessantly delivering a vocalization that is distinct from the loudsong (Zimmer \& Isler 2003). This type of behavior and associated vocalization is not known to occur in repertoires of Myrmotherula species. Other vocal differences were sought in an analysis of loudsongs (terminology following Willis 1968). A loudsong for the eight Epinecrophylla species was measured and compared to a loudsong of each of 25 Myrmotherula species and six additional populations that were selected to reflect intraspecific vocal variation in three species. One hundred and four vocal characters were derived from spectrogram measurements and from ratios of measurements. Following decision rules set out in earlier papers (e.g., Isler et al. 1998, 1999), diagnostic vocal differences between loudsongs of species of the two genera were found solely in frequency levels; Epinecrophylla species loudsongs were delivered at higher frequencies. In particular, when values were sorted in ascending order, there was no overlap between the two groups of species in the frequency measurement taken at the point of maximum intensity. Arrays of other measures of frequency (e.g., frequencies at highest point of individual notes) were consistent with that finding, except for values for Myrmotherula minor whose apparent loudsong is highly aberrant.

Nest architecture.-Nest architecture provides another invaluable clue to evolutionary history (Sheldon \& Winkler 1999). The value of nest characters in reconstructing avian relationships has been demonstrated in the Furnariidae, a closely related suboscine family (Zyskowski \& Prum 1999). Though not yet subject to a similarly rigorous phylogenetic analysis, preliminary organization of nest descriptions for the Thamnophilidae suggests that nest architecture in this family also offers insights into phylogeny (Zimmer \& Isler 2003). Nests known for three Epinecrophylla species are domedor oven-shaped nests with oblique or side entrances; nests of the remaining five species are unknown. Of the $14 \mathrm{Myr}$ motherula species for which nests have been described (nests of 13 species are unknown), all are deep cups, with the depth often approaching the width (Zimmer \& Isler 2003). Although nests of fewer than half of the Epinecrophylla species are known, this apparent major difference in nest architecture provides supporting evidence for the separation of species into the two genera.

Foraging behavior. - Curled dead leaves suspended in the vegetation are abundant in many Neotropical forests and provide a specialized opportunity for avian foraging, thus adding to species diversity (Terborgh 1980). Testing this concept in an elevational transect in Bolivia, Remsen \& Parker (1984) identified a number of dead-leaf searchers which they grouped into three categories: Specialists $(>75 \%$ of observations), Regular Users (25-75\% of observations, and Occasional Users ( $<25 \%$ of observations). The two Epinecrophylla species in the area were among the Specialists. Rosenberg (1990a, 1990b, 1997) extended these studies further in three locations and showed that what separated dead-leaf Specialists, including three Epinecrophylla species, from other birds that inspected dead leaves less often was their highly stereotyped manipulation of the dead leaves with their bills or feet. Numerous other studies (e.g., Greenberg \& Gradwohl 1997, Stotz 1990, other papers listed in Zimmer \& Isler 2003) also reported that all eight Epinecrophylla species forage almost exclusively at isolated dead-leaf clusters. In contrast, Myrmotherula species typically perchglean or sally-glean arthropods from a variety of surfaces including live leaves, 
stems, twigs, moss, and vines (Zimmer \& Isler 2003). No Myrmotherula species is a dead-leaf Specialist. Although $M$. guttata, M. hauxwelli, M. behni, M. urosticta, $M$. snowi, and $M$. longipennis are Regular Users and probe dead leaves with their bills, they do not manipulate them in the manner of Epinecrophylla species. In addition, $M$. iheringi is a Regular User in bamboo, and a number of other species (M. longicauda, M. gularis, M. axillaris outside southeastern Brazil, M. schisticolor, M. sunensis, M. minor, M. menetriesii, $M$. assimilis) probe dead-leaf clusters occasionally. Interestingly, in southeastern Brazil, where no Epinecrophylla species occurs, M. axillaris luctuosa is a Regular User but strikes the dead-leaf clusters with its bill to dislodge insects rather than manipulating them in the manner of Epinecrophylla species. The distinctive foraging specialization of Epinecrophylla species further supports their placement in a distinctive genus.

Etymology.-The feminine generic name is taken from the Greek epi (on), necro (dead) and phyllo (leaf), meaning "on the dead leaf," reflecting the strong predilection of members of the genus to search for insects on dead hanging leaves.

\section{Discussion}

Placement of the new genus within the taxonomic sequence of the Thamnophilidae awaits further study, especially molecular analyses. Both Irestedt et al. (2004) and the ongoing study (Brumfield et al. in prep.) support a sister relationship between Epinecrophylla and Neoctantes. The following species, following the sequence and English names of Remsen et al. (31 January 2006) are included in the genus:

Epinecrophylla fulviventris (Lawrence, 1862) Checker-throated Antwren

Epinecrophylla gutturalis (Sclater \& Salvin, 1881) Brown-bellied Antwren
Epinecrophylla leucophthalma (Pelzeln, 1869) White-eyed Antwren

Epinecrophylla haematonota (Sclater, 1857) Stipple-throated Antwren

Epinecrophylla fjeldsaai (Krabbe, Isler, Isler, Whitney, Alvarez, \& Greenfield, 1999) Brown-backed Antwren

Epinecrophylla spodionota (Sclater \& Salvin, 1880) Foothill Antwren

Epinecrophylla ornata (Sclater, 1853) Ornate Antwren

Epinecrophylla erythrura (Sclater, 1890) Rufous-tailed Antwren

Populations of E. ornata differ from the other seven Epinecrophylla species in the following ways: male throat solid black; female throat black spotted white except in E. o. hoffmannsi in which the female lacks this feature; more extensively gray plumage in E. o. atrogularis and E. $O$. meridionalis; shorter tail (33-38 $\mathrm{mm})$; and rectrices tipped white in the nominate form and in E. o. saturata.

In our considerations, we paid particular attention to Myrmotherula gularis, a species endemic to southeastern Brazil that superficially bears resemblance to members of the stipple-throated assemblage, in having a black throat spotted white (male) or a black and white spotted throat (female), extensively brown plumage, and dark wing coverts apically tipped white. Our molecular study found $M$. gularis not to be a member of the stipplethroated clade nor sister to it. In addition, other morphological and behavioral characteristics of $M$. gularis were inconsistent with those of Epinecrophylla species. The tail of $M$. gularis is considerably shorter (25-28 $\mathrm{mm})$ than any Epinecrophylla species, its vocal repertoire lacks the agonistic song typical of Epinecrophylla repertoires; its nest is a deep cup rather than a dome; and it typically perch-gleans and sally-gleans in live vegetation near the ground rather than foraging in hanging dead leaves (Zimmer \& Isler 2003). The evidence clearly demonstrates that the 
stippled throat of $M$. gularis is an example of homoplasy and that $M$. gularis is not a member of the stipple-throated assemblage. The generic placement of $M$. gularis awaits further results of molecular studies now underway.

\section{Acknowledgments}

We are extremely grateful to R. C. Banks who provided editorial guidance as the manuscript was being prepared. D. Nicholson and G. R. Graves provided additional support. J. G. Tello and an anonymous reviewer made a number of helpful comments in their reviews of the submitted manuscript.

\section{Literature Cited}

Cory, C. B., \& C. E. Hellmayr. 1924. Catalogue of birds of the Americas. Pteroptochidae Conopophagidae - Formicariidae.-Field Museum of Natural History (Zoological Series) 13, Pt. 3:1-369.

Gradwohl, J., \& R. Greenberg. 1984. Search behavior of the Checker-throated Antwren foraging in aerial leaf litter.-Behavioral Ecology and Sociobiology 15:281-285.

Greenberg, R., \& J. Gradwohl. 1997. Territoriality, adult survival, and dispersal in the Checkerthroated Antwren in Panama.-Journal of Avian Biology 28:103-110.

Hackett, S. J., \& K. V. Rosenberg. 1990. Comparison of phenotypic and genetic differentiation in South American antwrens (Formicariidae).-Auk 107:473-489.

Irestedt, M., J. Fjeldså, J. A. A. Nylander, \& P. G. P. Ericson. 2004. Phylogenetic relationships of typical antbirds (Thamnophilidae) and test of incongruence based on Bayes factors.-Bio Med Central Evolutionary Biology 4:23.

Isler, M. L., P. R. Isler, \& B. M. Whitney. 1998. Use of vocalizations to establish species limits in antbirds (Passeriformes; Thamnophilidae).Auk 115:577-590.

es limits in antbirds (Passeriformes; Thamnophilidae): the Myrmotherula surinamensis complex.Auk 116:83-96.

Krabbe, N., M. L. Isler, P. R. Isler, B. M. Whitney, J. Alvarez-Alonso, \& P. J. Greenfield. 1999. A new species in the Myrmotherula haematonota superspecies (Aves; Thamnophilidae) from the western Amazonian lowlands of Ecuador and Peru.-Wilson Bulletin 111:157-165.

Lawrence, G. N. 1862. Catalogue of a collection of birds, made in New Grenada, by James McLearnan, Esq., of New York, with notes and descriptions of new species. Part 3.Annals of the Lyceum of Natural History, New York 7:461-479.

Pelzeln, A. von. 1869 (1868). Zur Ornithologie Brasiliens, Resultate von Johann Natterers Reisen in den Jahren 1817 bis 1835. Abth. 2. Wien: A. Pichler's Witwe \& Sohn.

Remsen, J. V., Jr., et al. Version [31 January 2006]. A classification of the bird species of South America. American Ornithologists' Union, http://www.museum.lsu.edu/ Remsen/SACC Baseline.html.

, \& T. A. Parker III. 1984. Arboreal deadleaf-searching birds of the Neotropics.Condor 86:36-41.

Rosenberg, K. V. 1990a. Dead-leaf foraging specialization in tropical forest birds: measuring resource availability and use. Pp. 360-368. in M. L. Morrison, C. J. Ralph, J. Verner, and J. R. Jehl, Jr., eds., Avian foraging: theory, methodology, and applications. Studies in Avian Biology 13, 515 pp.

. 1990b. Dead-leaf foraging specialization in tropical forest birds. Ph.D. dissertation. Louisiana State University, Baton Rouge, Louisiana, $72 \mathrm{pp}$.

. 1997. Ecology of dead-leaf foraging specialists and their contribution to Amazonian diversity. Pp. 673-700. in J. V. Remsen, Jr., ed., Studies in Neotropical Ornithology Honoring Ted Parker, Ornithological Monographs 48, 918 pp.

Sclater, P. L. 1853. Letter.-Revue et magasin de zoologie pure et appliquée. 2nd ser. 5:479-480. . 1857. Characters of some apparently new species of American ant-thrushes.-Proceedings of the Zoological Society of London, pt. 25:46-48.

1890. Catalogue of the birds in the British Museum. Vol. 15. London: British Museum, $371 \mathrm{pp}$.

, \& O. Salvin. 1880. On new birds collected by Mr. C. Buckley in eastern Ecuador.Proceedings of the Zoological Society of London 1880:155-161. , \& . 1881. Descriptions of some new species of South-American birds of the families Tyrannidae and Formicariidae.-Ibis 4th ser. 5:267-271.

Sheldon, F. H., \& D. W. Winkler. 1999. Nest architecture and avian systematics.-Auk 116:875-877. 
Stotz, D. F. 1990. Foraging behavior and morphology in the avian genus Myrmotherula. Unpbl. Ph.D. dissertation, Chicago, Illinois: University of Chicago, $258 \mathrm{pp}$.

Terborgh, J. W. 1980. Causes of tropical species diversity.-Proceedings XVII International Ornithological Congress (1978):955-961.

Willis, E. O. 1967. The behavior of Bicolored Antbirds. University of California Publications in Zoology 79, University of California Press, Berkeley and Los Angeles, 127 pp.
Zimmer, K. J., \& M. L. Isler. 2003. Family Thamnophilidae (Typical Antbirds). Pp. 448-681. in J. del Hoyo, A. Elliot, and D. A. Christie, eds., Handbook of the Birds of the World, Vol. 8. Broadbills to Tapaculos. Lynx Edicions, Barcelona, 845 pp.

Zyskowski, K., \& R. O. Prum. 1999. Phylogenetic analysis of the nest architecture of Neotropical ovenbirds (Furnariidae).-Auk 116:891911.

Associate Editor: Gary R. Graves 